\title{
MODELING ABOVEGROUND BIOMASS OF TAMARIX RAMOSISSIMA IN THE ARKANSAS RIVER BASIN OF SOUTHEASTERN COLORADO, USA
}

\author{
Paul Evangelista1,3,4, Sunil Kumar1,3, Thomas J. Stohlgren²,3, \\ Alycia W. Crall1,3, and Gregory J. Newman ${ }^{1,3}$
}

\begin{abstract}
Predictive models of aboveground biomass of nonnative Tamarix ramosissima of various sizes were developed using destructive sampling techniques on 50 individuals and four $100-\mathrm{m}^{2}$ plots. Each sample was measured for average height $(\mathrm{m})$ of stems and canopy area $\left(\mathrm{m}^{2}\right)$ prior to cutting, drying, and weighing. Five competing regression models $(P<0.05)$ were developed to estimate aboveground biomass of $T$. ramosissima using average height and/or canopy area measurements and were evaluated using Akaike's Information Criterion corrected for small sample size $\left(\mathrm{AIC}_{c}\right)$. Our best model $\left(\mathrm{AIC}_{c}=-148.69, \Delta \mathrm{AIC}_{c}=0\right)$ successfully predicted $T$. ramosissima aboveground biomass $\left(\mathrm{R}^{2}=0.97\right)$ and used average height and canopy area as predictors. Our 2nd-best model, using the same predictors, was also successful in predicting aboveground biomass $\left(\mathrm{R}^{2}=0.97, \mathrm{AIC}_{c}=-131.71, \Delta \mathrm{AIC}_{c}=16.98\right)$. A 3rd model demonstrated high correlation between only aboveground biomass and canopy area $\left(\mathrm{R}^{2}=0.95\right)$, while 2 additional models found high correlations between aboveground biomass and average height measurements only $\left(\mathrm{R}^{2}=0.90\right.$ and 0.70 , respectively). These models illustrate how simple field measurements, such as height and canopy area, can be used in allometric relationships to accurately predict aboveground biomass of $T$. ramosissima. Although a correction factor may be necessary for predictions at larger scales, the models presented will prove useful for many research and management initiatives.
\end{abstract}

Key words: Tamarix ramosissima, tamarisk, aboveground biomass, invasions, nonnative species, regression models, canopy area, complete harvest.

Native riparian ecosystems throughout the southwestern United States are being altered by the rapid invasion of Tamarix species. Introduced from Eurasia in the early 1800s for erosion control, windbreaks, and ornamentation, Tamarix was acclaimed for its ability to withstand drought, heat, and diverse soil conditions (Carleton 1914, DiTomaso 1998). These views began to change by the mid-1900s as resource managers witnessed Tamarix's remarkable ability to spread and cause dramatic effects on native flora, wildlife habitat, and hydrologic processes (Christensen 1962, Robinson 1965, Harris 1966). Although researchers have been actively examining the effects of Tamarix on a number of ecological processes (Campbell and Dick-Peddie 1964, Carman and Brotherson 1982, Stromberg 1998, Sher et al. 2002), there is still little quantitative information on biomass or transpiration rates, and predictive regression models or allometric equations have not been previously developed. This is of particular concern to resource managers who work where water yield is heavily managed and biomass estimates are required for many management, monitoring, and restoration efforts. In addition to clarifying potential transpiration and water use (Sala et al. 1996), biomass measurements are commonly utilized in monitoring the effectiveness of restoration efforts (Johnson et al. 1986, Oomes 1992) and in evaluating leaf area (Nagler et al. 2004), nutrient flow and productivity (Kelly et al. 1974, Cannell et al. 1987), wildlife habitats (Wiens and Rotenberry 1981, Rea and Gillingham 2001), fire effects and hazards (Abrams et al. 1986), disturbance (McWilliam et al. 1993), and impacts of nonnative plant invasions (Haase and Haase 1995, Standish et al. 2001). Many resource management agencies are also actively engaged in Tamarix mitigation efforts (A. Hughes, Grand Staircase-Escalante National Monument, personal communication; F. Pannebaker, National Park Service, personal communication; Van Landingham, Colorado State Forest Service, personal communication). A reliable method for estimating biomass would enhance their ability to plan budgets and

\footnotetext{
${ }^{1}$ Natural Resource Ecology Laboratory, Colorado State University, Fort Collins, CO 80523-1499

${ }^{2}$ USGS Fort Collins Science Center, 2150 Centre Ave., Bldg C, Fort Collins, CO 80526-8118.

${ }^{3}$ National Institute of Invasive Species Science. Web site: http://www.niiss.org

[4E-mail: paulevan@nrel.colostate.edu
} 
identify the necessary labor and equipment required for Tamarix removal.

Although there are several methods available for estimating the biomass of various tree species (Whittaker and Woodwell 1968, Monk et al. 1970, Swank and Schreuder 1974, Young 1976, Crow 1983, Pastor et al. 1984), there is yet to be an adequate method for estimating the biomass of Tamarix and other multistemmed shrubs. Diameter measurements (diameter at breast height, dbh) are frequently used and have strong correlations with biomass (Prescott et al. 1989, Arthur and Fahey 1990, Harcombe et al. 1993); however, measurements of dbh are difficult to acquire for Tamarix due to its irregular growth patterns, multiple stems, and tendency to persist in dense stands. A single Tamarix tree may have a single bole or dozens of stems protruding from the ground. Variations in growth patterns are often related to species characteristics, fluctuations in resource availability, or various disturbances. These discrepancies in stem growth and the labor associated with collecting field measurements have discouraged the collection of dbh measurements and limited most Tamarix surveys to height and canopy cover (Campbell and Dick-Peddie 1964, Wilkinson 1966, Nagler et al. 2004).

There are 2 methods that are generally employed for measuring biomass of single-bole trees. The first is complete harvesting, or destructive sampling, where an individual or group of individuals is measured, cut, dried, and weighed (Grier and Logan 1977, Gholz 1980, Jenkins et al. 2001). Although this method produces accurate results, it is often labor intensive, costly, and impractical, and limits possibilities of temporal studies. The 2nd method uses regression models based on other tree dimensions that are more easily measured, such as dbh, height, and canopy cover (Swamy et al. 2006). Due to the constraints associated with dbh measurements of Tamarix, we examined the potential of modeling Tamarix ramosissima biomass using only height and cover measurements.

\section{Methods}

\section{Study Area}

Biomass data were collected from 2 different areas in the Arkansas River basin of southeastern Colorado. In October 2005 we collected data at the Oxbow State Wildlife Area (SWA) and in February 2005 at Grenada SWA. Oxbow SWA is in Otero County $\left(38.04^{\circ} \mathrm{N}, 103.41^{\circ} \mathrm{W}\right)$ on the south bank of the Arkansas River near Bent's Old Fort National Historic Site. The stand covers approximately 164 ha at $1219 \mathrm{~m}$ elevation and contains large expanses of mixedsize T. ramosissima. The Colorado Division of Wildlife, the Colorado State Forest Service, and the National Park Service have been removing T. ramosissima at Oxbow SWA since 2001. Grenada SWA is located east of Oxbow SWA and also borders the south bank of the Arkansas River. Located in Prowers County $\left(38.04^{\circ} \mathrm{N}, 102.220^{\circ} \mathrm{W}\right)$, Grenada SWA has an elevation of about $1036 \mathrm{~m}$ and covers approximately 1486 ha. Tamarix ramosissima at this site is largely evenly sized with more than $90 \%$ of individuals categorized as mature (height > $3 \mathrm{~m}$ ). Since 2003 the Colorado Division of Wildlife has aggressively removed $T$. ramosissima to open river access and promote Populus regeneration. This region is believed to be 1 of the earliest Tamarix infestations in Colorado. First reported in the early 1900s, T. ramosissima has since become the dominant species along much of the Arkansas River, its tributaries, and neighboring reservoirs (Robinson 1965, Lindauer 1985, F. Pannebaker, National Park Service, personal communication).

\section{Field Sampling and Laboratory Procedures}

During our 1st field campaign at Oxbow SWA, we selected $25 \mathrm{~T}$. ramosissima trees of various height classes ranging from $0.6 \mathrm{~m}$ to $5 \mathrm{~m}$ for complete harvesting and biomass measurements. At the time of sampling, T. ramosissima trees were in full foliage and had only remnant flowers. Before cutting, we established a scaledependent plot around each tree to determine area and percent canopy cover. The scaledependent plot is a square or rectangular design that is adjustable to the dimensions of an individual tree or stand of interest. The area of each plot varied in size, having different lengths and widths based on the size and canopy cover of the tree (or stand) being measured. The length and width of each plot were measured to determine the plot's area $\left(\mathrm{m}^{2}\right)$. We estimated average height (m) and total percent canopy cover for all sampled trees, including dead stems. Individual trees were then cut at the ground surface and carefully moved to tarps to ensure that all parts were collected and weighed. Each 
tree was weighed using a portable scale immediately following cutting (total green weight). Foliage (including small diameter green stems) was then separated from woody parts, and each part was weighed separately to determine weight distribution and ratios.

Next, we subsampled both foliage $(n=20)$ and woody parts with mixed diameters $(n=20)$ for drying. Larger woody parts were split or cut into smaller pieces to hasten the drying process. Each subsample was placed in a $20 \times 30-\mathrm{cm}$ preweighed burlap bag and transported to the Natural Resource Ecology Laboratory, Colorado State University, Fort Collins. Subsamples were oven-dried at $60^{\circ} \mathrm{C}$ and weighed regularly until weights became constant. Foliage subsamples took 7 days for weights to stabilize, while woody parts took 14-18 days.

A 2nd field campaign was conducted in Grenada SWA to collect additional samples at the level of individual trees and at a stand level. At the time of sampling, nearly all of the foliage had fallen or was only weakly attached. We collected biomass data on the woody parts only, applying previous results from our weight distribution analyses in Oxbow SWA to estimate the weights of lost foliage. Using the same methods previously described (without foliage measurements), we harvested and measured an additional 25 T. ramosissima individuals, which ranged from $1.8 \mathrm{~m}$ to $6.1 \mathrm{~m}$ tall. Because leaves were absent, we gave careful consideration when estimating foliar percent coverage. Our estimates reflected probable cover if full foliage were present. Ten subsamples of woody parts with mixed diameters were collected for oven-drying. Additionally, we established four $10 \times 10-\mathrm{m}$ $\left(100-\mathrm{m}^{2}\right)$ plots for measurements. Prior to complete harvest of the $100-\mathrm{m}^{2}$ plots, we recorded number of trees, average height, and total percent canopy cover of T. ramosissima within each plot. Tamarix ramosissima trees on the edges of each plot were carefully cut along the $100-\mathrm{m}^{2}$ plot perimeters to determine whether or not branches were to be included in the sample. Woody parts and remnant foliage were separated, and only the woody parts were saved; the foliage and deadwood were discarded on the ground. All standing woody parts were weighed in the field and summed to determine total green woody weight for each stand. No litter or dead parts were considered.

\section{Statistical Analyses}

The canopy area $\left(\mathrm{m}^{2}\right)$ for each tree or plot was calculated by multiplying the plot area $\left(\mathrm{m}^{2}\right)$ by the percent canopy cover recorded in the field. Our analyses included all 50 individual tree samples and the four $100-\mathrm{m}^{2}$ plots $(n=54)$. A suite of candidate regression models for total aboveground biomass was developed using average height $(\mathrm{m})$ and canopy area $\left(\mathrm{m}^{2}\right)$, and their interaction terms as predictor variables. In all cases we used $P<0.05$ and tolerance levels $<0.95$ as the criteria to include a variable as a significant predictor. Regression analyses were conducted using the PROC REG procedure in SAS software (SAS Institute, Inc. 2004). Residuals from the models were plotted against fitted values to check nonlinearity, unequal variances, and outliers in the data (Zar 1999). Prior to regression analyses, total oven-dry aboveground biomass (TAGB; $\mathrm{kg}$ ) of T. ramosissima and canopy area were logtransformed to normalize these variables and meet the assumption of normality for regression models (Neter et al. 1996).

The candidate models were evaluated using Akaike's information criterion (AIC) and the information-theoretic approach (Burnham and Anderson 2002). Normally distributed errors with a constant variance were assumed for least-squares regressions. Since the number of observations was small $(n=54)$, we used AIC adjusted for small sample size (i.e., $\mathrm{AIC}_{c}$; see Burnham and Anderson 2002:66). We identified the best model with the lowest $\mathrm{AIC}_{c}$ and calculated $\mathrm{AIC}_{c}$ differences $\left(\Delta \mathrm{AIC}_{c i}\right)$ across all candidate models in the set. The best model has $\Delta \mathrm{AIC}_{c i}=0$ (Burnham and Anderson 2002:70-71).

For log-log regression models, taking antilogs of the previously transformed data to estimate total aboveground biomass induces an inherent bias "because the largest values are compressed on the logarithmic scale and thereby tend to have less 'leverage' than small values in making such an estimate" (Beauchamp and Olson 1973). Therefore, a correction factor (CF) has been recommended to account for this bias (Sprugel 1983). The CF for the models was calculated as follows (Sprugel 1983):

$$
\mathrm{CF}=\exp \left[\left(2.303 s_{\bar{x}}\right)^{2} / 2\right],
$$

where $s_{\bar{x}}$ is the standard error of the estimate of the regression model. The biomass estimates 
TABLE 1. Regression models for estimating Tamarix ramossissima total oven-dry aboveground biomass (TAGB; kg) using canopy area $\left(\mathrm{CA} ; \mathrm{m}^{2}\right)$ and average height $(\mathrm{Ht} ; \mathrm{m})$ as predictors. $P<0.0001$ for all models, $n=54$. AIC $c=$ Akaike's information criterion corrected for small sample size; $\Delta \mathrm{AIC}_{c i}=\mathrm{AIC}_{c i}-$ minimum $\mathrm{AIC}_{c} ; \mathrm{CF}$ is correction factor. The final estimates of $T$. ramossissima biomass $(\mathrm{kg})$ should be multiplied by $\mathrm{CF}$ to correct for bias. See text for details.

\begin{tabular}{|c|c|c|c|c|c|c|c|c|}
\hline $\begin{array}{l}\text { Model } \\
\text { no. }\end{array}$ & Model & $\begin{array}{l}\text { Coefficient } \\
\text { symbol }\end{array}$ & $\begin{array}{l}\text { Coefficient } \\
\text { value }\end{array}$ & $\begin{array}{c}\text { Partial } \\
\mathrm{R}^{2}\end{array}$ & $\mathrm{CF}$ & $\begin{array}{l}\text { Adj. } \\
\mathrm{R}^{2}\end{array}$ & $\mathrm{AIC}_{c}$ & $\Delta \mathrm{AIC}_{c}$ \\
\hline 1 & $\log _{10}(\mathrm{TAGB})=\mathrm{c}+\alpha \log _{10}(\mathrm{CA})+\beta \mathrm{Ht}+\gamma \mathrm{Ht}^{2}$ & $\begin{array}{l}\mathrm{c} \\
\alpha \\
\beta \\
\gamma\end{array}$ & $\begin{array}{r}-1.1993 \\
1.1090 \\
0.8595 \\
-0.0927\end{array}$ & $\begin{array}{l}0.947 \\
0.007 \\
0.014\end{array}$ & 1.17 & 0.966 & -148.69 & 0.00 \\
\hline 2 & $\log _{10}(\mathrm{TAGB})=\mathrm{c}+\alpha \log _{10}(\mathrm{CA})+\beta \mathrm{Ht}$ & $\begin{array}{l}c \\
\alpha \\
\beta\end{array}$ & $\begin{array}{r}-0.2968 \\
1.3621 \\
0.1324\end{array}$ & $\begin{array}{l}0.947 \\
0.007\end{array}$ & 1.24 & 0.952 & -131.71 & 16.98 \\
\hline 3 & $\log _{10}(\mathrm{TAGB})=\mathrm{c}+\alpha \log _{10}(\mathrm{CA})$ & $\begin{array}{l}\mathrm{c} \\
\alpha\end{array}$ & $\begin{array}{r}-0.0518 \\
1.5445\end{array}$ & & 1.28 & 0.946 & -126.75 & 21.93 \\
\hline 4 & $\log _{10}(\mathrm{TAGB})=\mathrm{c}+\alpha \mathrm{Ht}-\beta \mathrm{Ht}^{2}$ & $\begin{array}{l}c \\
\alpha \\
\beta\end{array}$ & $\begin{array}{r}-2.9543 \\
2.2312 \\
-0.2380\end{array}$ & $\begin{array}{l}0.707 \\
0.195\end{array}$ & 1.58 & 0.898 & -91.68 & 57.01 \\
\hline 5 & $\log _{10}(\mathrm{TAGB})=\mathrm{c}+\alpha \mathrm{Ht}$ & $\begin{array}{l}\mathrm{c} \\
\alpha\end{array}$ & $\begin{array}{r}-1.2616 \\
0.7902\end{array}$ & & 3.82 & 0.701 & -34.61 & 114.07 \\
\hline
\end{tabular}

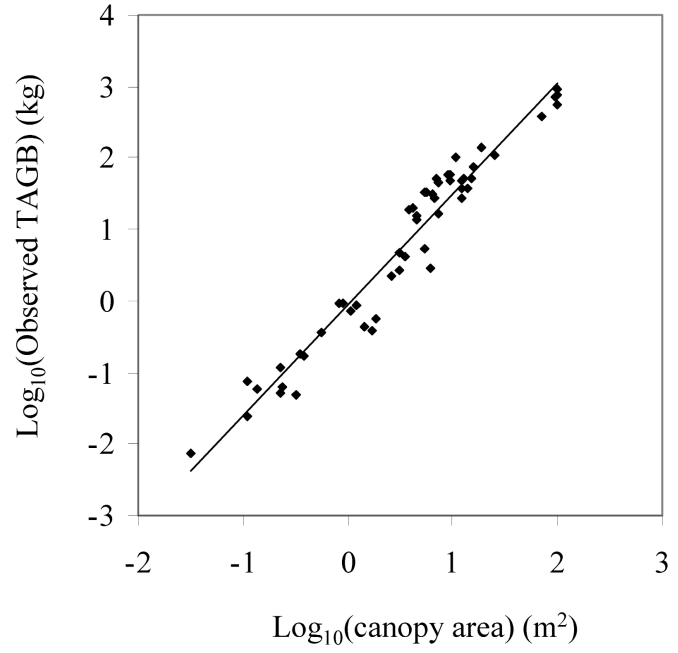

Fig. 1. Relationship between Tamarix ramosissima canopy area $\left(\mathrm{m}^{2}\right)$ and predicted total oven-dry aboveground biomass (TAGB; $\mathrm{kg}$ ) from model $3\left(\mathrm{R}^{2}=0.95, P<0.0001\right)$.

should be multiplied by the CF for unbiased estimation of total aboveground biomass (Sprugel 1983).

\section{Results}

Sampled trees from both sites ranged from $0.6 \mathrm{~m}$ average height and $0.03 \mathrm{~m}^{2}$ canopy area to $6.1 \mathrm{~m}$ average height and $69.5 \mathrm{~m}^{2}$ canopy area. At the Oxbow SWA site, total green weights of foliage were higher than green weights of woody parts for the 6 smallest $T$. ramosissima samples $(<1.5 \mathrm{~m}$ average height and $<1.1 \mathrm{~m}^{2}$ canopy area), while total green woody material constituted greater weights for 19 larger samples $(>1.5 \mathrm{~m}$ average height and $>1.1 \mathrm{~m}^{2}$ canopy area). Total oven-dry weights of foliage were higher than oven-dry weights of woody parts for only 4 samples $(<1.2 \mathrm{~m}$ average height and $<1.7 \mathrm{~m}^{2}$ canopy area) and greater for 21 samples $(>1.2 \mathrm{~m}$ average height and $>1.7 \mathrm{~m}^{2}$ canopy area). Mean dry weights from foliage collected at Oxbow SWA, on average, were reduced to $47.1 \%( \pm 2.3)$ and woody parts to $63.6 \%( \pm 0.6)$ of their green weights. Foliage represented, on average, 9.3\%, and woody material represented $90.7 \%$ of the total ovendry weights for all samples collected at Oxbow SWA. The total oven-dry aboveground biomass for the individual $T$. ramossissima trees varied from $0.007 \mathrm{~kg}$ to $375.81 \mathrm{~kg}$.

Five competing regression models were evaluated from a suite of candidate models (Table 1 ). The best model $\left(\mathrm{AIC}_{c}=-148.69, \Delta \mathrm{AIC}_{c}=0\right.$; Table 1) explained $97 \%$ of the variation in total oven-dry aboveground biomass (TAGB) of $T$. ramosissima and was highly significant $(P<$ $0.0001)$. It included both canopy area and average height as variables with canopy area being the strongest predictor of TAGB (partial $\mathrm{R}^{2}=0.95$ ). Similarly, the 2nd-best model 


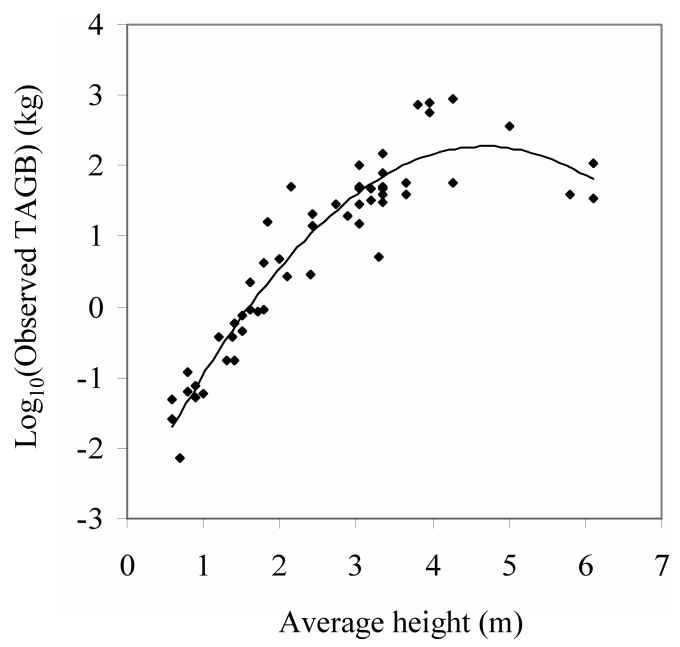

Fig. 2. Relationship between Tamarix ramosissima average height $(\mathrm{m})$ and predicted (TAGB; $\mathrm{kg}$ ) from model 4 $\left(\mathrm{R}^{2}=0.90, P<0.0001\right)$.

$\left(\mathrm{AIC}_{c}=-131.71, \Delta \mathrm{AIC}_{c}=16.98\right)$ also included canopy area and average height and explained $95 \%$ of the variation of TAGB. Canopy area for this model was equally as strong of a predictor as the 1st model (partial $\mathrm{R}^{2}=0.95$, Table 1 ). Other candidate models utilized either canopy area or average height only, and explained $70 \%$ to $95 \%$ of the variation in T. ramosissima TAGB (models 3-5; Table 1). The 3rd model related only canopy area to TAGB (Fig. 1) and explained 95\% of the variation $\left(\Delta \mathrm{AIC}_{c}=21.93\right.$; Table 1). Our 4th model considered average height (Fig. 2) and square of average height as predictors of TAGB and explained $90 \%$ of the variation $\left(\Delta \mathrm{AIC}_{\mathrm{c}}=\right.$ $57.01)$, whereas a 5 th model, which also considered only average height as a predictor, was the weakest model, explaining only $70 \%$ of the variation in TAGB. The results from our best model found a strong agreement between observed TAGB and predicted TAGB (Fig. 3, $\left.Y=0.0261+0.9674 X, \mathrm{R}^{2}=0.97\right)$.

\section{Discussion}

We were extremely encouraged by our ability to accurately predict $T$. ramosissima aboveground biomass from simple field measurements of cover and height (Table 1, Fig. 3). While additional destructive sampling in other areas will be needed to generalize the models, the individuals and stands used here are indistinguishable from many of our study sites else-

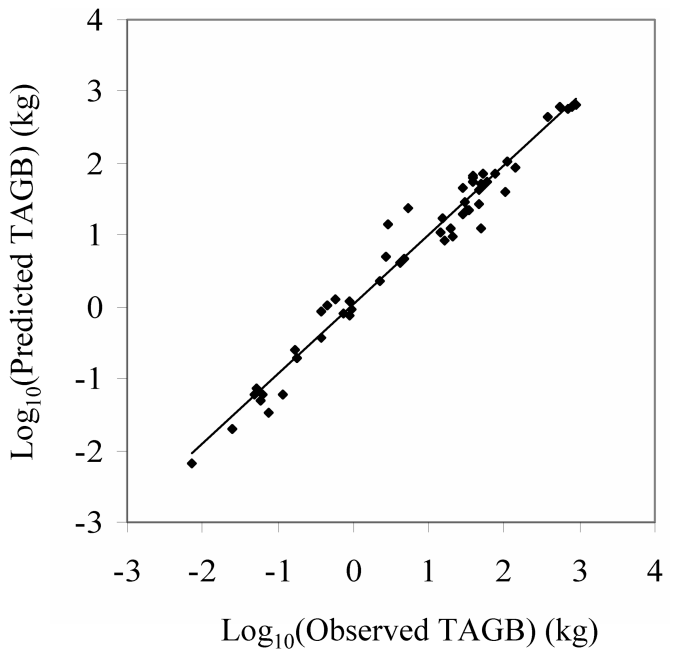

Fig. 3. Relationship between Tamarix ramosissima observed and predicted TAGB $\left(\mathrm{kg} ; \mathrm{R}^{2}=0.97, P<0.0001\right)$.

where in Colorado, New Mexico, and Utah. Our models may serve as a 1st approximation of aboveground biomass of $T$. ramosissima until additional samples are gathered from fringe populations, because there are high costs associated with collecting and analyzing this type of field data.

Although our models succeeded in identifying strong relationships between aboveground biomass and average height and canopy area (Fig. 3), there are still important caveats to consider. The models may be strongest when applied to T. ramosissima within the geographical vicinity of our study area, and results may differ in other landscapes or at larger scales, or the results may not be applicable throughout the distributional range of T. ramosissima. Ecological variables such as climate, water availability, or disturbance regimes are likely to affect growth formations and stand structure of T. ramosissima. Therefore, our best model would provide much better biomass estimates if applied to the areas that have a range of variation in average height and canopy area similar to this study; this model may underestimate or overestimate biomass outside this range. Furthermore, in an effort to preserve simplicity, our models do not consider diameter, age, or stem numbers of sampled trees, all of which may contribute to varying biomass estimates. Also, our study measured actual foliage weights from only half of the sampled trees, using the results to estimate the other half. 
Although dry weights of foliage are unlikely to vary much, we must acknowledge that some bias in the model can be expected.

These models may not be suited for other species of Tamarix and should be evaluated prior to application, or new models should be developed using similar methodology. In particular, our models that utilized average height and canopy area measurements independently to predict aboveground biomass (models 3, 4, and 5) are limited to the site of sampled trees. For example, model 3, which utilizes canopy area as the only predictor variable, does not distinguish between an area infested by new seedlings and an area infested by a mature stand; yet there will be obvious differences in aboveground biomass between the 2 sites. Despite these limitations, our best model, which utilizes both average height and canopy area (model 1, Table 1), has the strongest potential to provide researchers and resource managers with a rapid and easy method to determine aboveground biomass of $T$. ramosissima. However, this model is also sensitive to canopy area, and a correction factor for canopy area may be necessary for biomass predictions over larger areas (e.g., $>100 \mathrm{~m}^{2}$ ).

These models can be integrated with a variety of research initiatives such as determining water usage and productivity, monitoring the effectiveness of biocontrol agents, and developing remote sensing capabilities. Resource managers can employ these models to assess fire risks and changes in riparian habitats, and to calculate costs of herbicides and other control treatments. With some additional field work, these biomass models can also be applied for mapping landscape-level Tamarix biomass using remotely sensed data (e.g., Hall et al. 2006). To broaden the applicability of aboveground biomass models, similar research initiatives are needed throughout the distribution range of $T$. ramosissima to assess the variability associated with geography and climate. Additionally, large-scale sampling from other invaded areas that have trees of varying height and canopy area would further enhance the models' utility for stand estimates and its application across the western United States.

\section{ACKNOWLEDGMENTS}

Funding for this study was provided by the U.S. Geological Survey (USGS). We would like to thank the Colorado Division of Wildlife (CDOW) for permitting us to conduct this research on state wildlife areas. Additional appreciation is given for the support and cooperation of the Colorado State Forest Service (CSFS), Bent's Old Fort National Park (NPS), and the Natural Resource Ecology Laboratory (NREL). In particular, we thank Kevin Kaczmarek (CDOW), Shelly Van Landingham (CSFS), Donna Davis (CSFS), Terry Marinelli (CDOW), Jeremy Goodell (NREL), and Dan MacKinnon (NREL).

\section{Literature Cited}

Abrams, M.D., A.K. Knapp, and L.C. Hulbert. 1986. A ten-year record of aboveground biomass in a Kansas tallgrass prairie: effects of fire and topographic position. American Journal of Botany 73:1509-1515.

Arthur, M.A., AND T.J. FAhEy. 1990. Mass and nutrient content of decaying boles in an Engelmann sprucesubalpine fir forest, Rocky Mountain National Park, Colorado. Canadian Journal of Forest Research 20: 730-737.

Beauchamp, J.J., and J.S. Olson. 1973. Corrections for bias in regression estimates after logarithmic transformation. Ecology 54:1403-1407.

Burnham, K.P., AND D.R. Anderson. 2002. Model selection and multimodel inference: a practical information-theoretical approach. Springer, New York.

Campbell, C.J., AND W.A. Dick-PedDie. 1964. Comparison of phreatophyte communities on the Rio Grande in New Mexico. Ecology 45:492-502.

Cannell, M.G.R., R. Milne, L.J. Sheppard, and M.H. UnsworTh. 1987. Radiation interception and productivity of willow. Journal of Applied Ecology 24: 261-278.

Carleton, M.A. 1914. Adaptation of the tamarisk for dry lands. Science 39:692-694.

Carman, J.G., and J.D. Brotherson. 1982. Comparisons of sites infested and not infested with saltcedar (Tamarix pentandra) and Russian olive (Elaeagnus angustifolia). Weed Science 30:360-364.

Christensen, E.M. 1962. The rate of naturalization of Tamarix in Utah. American Midland Naturalist 68:5157.

Crow, T.R. 1983. Comparing biomass regressions by site and stand age for red maple. Canadian Journal of Forest Research 13:283-288.

DiTomaso, J.M. 1998. Impact, biology, and ecology of saltcedar (Tamarix spp.) in the southwestern United States. Weed Technology 12:326-336.

GHoLZ, H.L. 1980. Structure and productivity of Juniperus occidentalis in central Oregon. American Midland Naturalist 103:251-261.

Grier, C.C., AND R.S. Logan. 1977. Old-growth Pseudotsuga menziesii communities of a western Oregon watershed: biomass distribution and production budgets. Ecological Monographs 47:373-400.

HaAse, R., and P. HaAse. 1995. Above-ground biomass estimates for invasive trees and shrubs in the Pantanal of Mato Grosso, Brazil. Forest Ecology and Management 73:29-35. 
Hall, R.J., R.S. Skakun, E.J. Arsenault, and B.S. Case. 2006. Modeling forest stand structure attributes using Landsat ETM + data: application to mapping of aboveground biomass and stand volume. Forest Ecology and Management 225:378-390.

Harcombe, P.A., G.N. Cameron, and E.G. Glumac. 1993. Above-ground net primary productivity in adjacent grassland and woodland on the coastal plain of Texas, USA. Journal of Vegetation Science 4:521-530.

HARRIS, D.R. 1966. Recent plant invasions in the arid and semi-arid Southwest of the United States. Annals of the Association of American Geographers 56:408-422.

Jenkins, J.C., R.A. Birdsey, And Y. PAN. 2001. Biomass and NPP estimation for the mid-Atlantic region (USA) using plot-level forest inventory data. Ecological Applications 11:1174-1193.

Johnson, A.F., W.G. Abrahamson, and K.D. McCrea. 1986. Comparison of biomass recovery after fire of a seeder (Ceraiola ericoides) and a sprouter (Quercus inopina) species from south-central Florida. American Midland Naturalist 116:423-428.

Kelly, J.M., G.M. Van Dyne, And W.F. Harris. 1974. Comparison of three methods of assessing grassland productivity and biomass dynamics. American Midland Naturalist 92:357-369.

Lindauer, I.E. 1985. A comparison of the plant communities of the South Platte and Arkansas River drainages in eastern Colorado. Southwestern Naturalist 28:249-259.

McWilliam, A.L.C., J.M. Roberts, O.M.R. Cabral, M.V.B.R. Leitao, A.C.L. De Costa, G.T. Maitelli, AND C.A.G.P. Zamparoni. 1993. Leaf area index and above-ground biomass of terra firme rain forest and adjacent clearings in Amazonia. Functional Ecology $7: 310-317$.

Monk, C.D., G.I. Child, AND S.A. Nicholson. 1970. Biomass, litter and leaf surface area estimates of an oakhickory forest. Oikos 21:138-141.

Nagler, P.L., E.P. Glenn, T.L. Thompson, and A. Huete. 2004. Leaf area index and normalized difference vegetation index as predictors of canopy characteristics and light interception by riparian species on the Lower Colorado River. Agricultural and Forest Meteorology 125(1-2):1-17.

Neter, J., M.H. Kutner, C.J. Nachtsheim, and W. Wasserman. 1996. Applied linear statistical models: regression, analysis of variance, and experimental designs. Irwin, Chicago, IL.

Oomes, M.J.M. 1992. Yield and species density of grasslands during restoration management. Journal of Vegetation Science 3:271-274.

Pastor, J., J.D. ABer, And J.M. Melillo. 1984. Biomass prediction using generalized allometric regressions for some Northeast tree species. Forest Ecology and Management 7:265-274.

Prescott, C.E., J.P. Corbin, and D. Parkinson. 1989. Biomass, productivity, and nutrient-use efficiency of aboveground vegetation in four Rocky Mountain coniferous forests. Canadian Journal of Forest Research 19:309-317.

REa, R.V., And M.P. Gillingham. 2001. The impact of the timing of brush management on the nutritional value of woody browse for moose Alces alces. Journal of Applied Ecology 38:710-719.

Robinson, T.R. 1965. Introduction, spread, and areal extent of saltcedar (Tamarix) in the western states. U.S. Geological Survey, Professional Paper 491(A). U.S. Geological Survey.

Sala, A., S.D. Smith, And D.A. DevitT. 1996. Water use by Tamarix ramosissima and associated phreatophytes in a Mojave Desert floodplain. Ecological Applications 6:888-898.

SAS Institute, InC. 2004. SAS for Windows. Version 9.1. SAS Institute, Inc., Cary, NC.

Sher, A.A., D.L. Marshall, and J.P. Taylor. 2002. Establishment patterns of native Populus and Salix in the presence of invasive nonnative Tamarix. Ecological Applications 12:760-772.

SprugEL, D.G. 1983. Correcting for bias in log-transformed allometric equations. Ecology 64:209-210.

Standish, R.J., A.W. Robertson, And P.A. Williams. 2001. The impact of an invasive weed Tradescantia fluminensis on native forest regeneration. Journal of Applied Ecology 38:1253-1263.

StromberG, J.C. 1998. Dynamics of Fremont cottonwood (Populus fremontii) and saltcedar (Tamarix chinensis) populations along the San Pedro River, Arizona. Journal of Arid Environments 40:133-155.

Swamy, S.L., A. Mishra, and S. Puri. 2006. Comparison of growth, biomass and nutrient distribution in five promising clones of Populus deltoides under an agrisilviculture system. Bioresource Technology 97: 57-68.

Swank, W.T., AND H.T. SChreuder. 1974. Comparison of three methods of estimating surface area and biomass for a forest of young eastern white pine. Forest Science 20:91-100.

WhitTaker, R.H., and G.M. WoOdWELl. 1968. Dimension and production relations of trees and shrubs in the Brookhaven Forest, New York. Journal of Ecology $56: 1-25$.

Wiens, J.A., And J.T. Rotenberry. 1981. Habitat associations and community structure of birds in shrubsteppe environments. Ecological Monographs 51:2141 .

WiLkinson, R.E. 1966. Seasonal development of anatomical structures of saltcedar foliage. Botanical Gazette 127:231-234.

Young, H.E. 1976. A summary and analysis of weight table studies. Pages 251-282 in H.E. Young, editor, Oslo biomass studies, University of Maine, Orono.

ZAR, J.H. 1999. Biostatistical analysis. Prentice Hall, Upper Saddle River, NJ. 663 pp.

Received 9 June 2006 Accepted 9 February 2007 